\title{
Immune cellular profile of bisphosphonate-related osteonecrosis of the jaw
}

\author{
PG de Barros Silva ${ }^{1}$, CC de Oliveira ${ }^{1}$, LAC Brizeno ${ }^{2}$, DVT Wong ${ }^{3}$, RCP Lima Júnior ${ }^{3}$, RP Gonçalves ${ }^{4}$, \\ FB Sousa ${ }^{1}$, MRL Mota $^{1}, \mathrm{R}_{\text {de Albuquerque Ribeiro }}{ }^{3}$, APNN Alves ${ }^{1}$ \\ ${ }^{1}$ Department of Dental Clinic, Division of Oral Pathology, Faculty of Pharmacy, Dentistry and Nursing, Federal University of Ceara, \\ Fortaleza, Ceara; ${ }^{2}$ Department of Biotechnology, Faculty of Biotechnology, Federal University of Ceara, Fortaleza, Ceara; \\ ${ }^{3}$ Department of Physiology and Pharmacology, Faculty of Medicine, Federal University of Ceara, Fortaleza, Ceara; ${ }^{4}$ Department of \\ Clinical Analysis, Faculty of Pharmacy, Dentistry and Nursing, Federal University of Ceara, Fortaleza, Ceara, Brazil
}

OBJECTIVES: Characterize the cell profile and immunostaining of proinflammatory markers in an experimental model of bisphosphonate-related osteonecrosis of the jaw (BRONJ).

MATERIALS AND METHODS: Male Wistar rats $(n=6-$ 7) were treated chronically with saline solution or zoledronic acid (ZA) at $0.04,0.20$, and $1.00 \mathrm{mg} \mathrm{kg}^{-1}$ $\left(1.4 \times 10^{-7}, 6.9 \times 10^{-6}\right.$, and $\left.3.4 \times 10^{-5} \mathrm{~mol} \mathrm{~kg}^{-1}\right)$, and subsequently, the first left inferior molar was extracted. Were performed counting of viable and empty osteocyte lacunae, viable and apoptotic osteoclasts, polymorphonuclear neutrophil, mast cells (toluidine blue), and the positive presence cells for CD68, tumor necrosis factor-alpha (TNF- $\alpha$ ), IL (interleukin)-I $\beta$, inducible nitric oxide synthase (iNOS), nuclear factor-kappa B (NF-kB) and IL- I 8 binding protein (IL- I 8 bp).

RESULTS: BRONJ was showed in ZA treated with $\mathbf{0 . 2 0}$ and $1.00 \mathrm{mg} \mathrm{kg}^{-1}$. There is a dose dependent increase in percentage of empty osteocyte lacunae $(P<0.00 I)$ and apoptotic osteoclasts $(P<0.00 I)$, counting of total osteoclasts $(P=\mathbf{0 . 0 0 3})$, polymorphonuclear neutrophil cells $(P=0.009)$, cytoplasmic-positive cells of CD68 $(P<0.00 I)$, TNF- $\alpha(P=0.00 I)$, IL-I $\beta(P=0.00 I)$, iNOS $(P<0.001)$, NF-kB $(P=0.006)$, and nuclear-positive cells of NF-kB $(P=0.0 I I)$. Consequently, there is no difference in mast cells $(P=0.957)$, and IL- 18 bp immunostaining decreases dose dependently $(P=0.005)$.

CONCLUSIONS: BRONJ is characterized by increases in immunostaining for proinflammatory markers and NF-kB and inversely associated with cells exhibiting IL-I 8 bp.

Correspondence: Paulo Goberlânio de Barros Silva, Ms, Division of Oral Pathology, Department of Clinical Dentistry, School of Dentistry, Federal University of Ceará, Alexandre Barauna Street, 949, Rodolfo Teofilo, 60430-160, Fortaleza, Ceará, Brazil. Tel: +55 $8533668421,+5585$ 8705 7151, Fax: 558533668421 ,

E-mail: paulo_goberlanio@yahoo.com.br

In memorian of Ronaldo de Albuquerque Ribeiro

Received 18 January 2016; revised 9 April 2016; accepted 2 May 2016
Oral Diseases (2016) 22, 649-657

Keywords: bisphosphonate-associated osteonecrosis of the jaw; tumor necrosis factor-alpha; interleukin-I; nitric oxide synthase type II; NF-kappa B; IL-I8 binding proteins

\section{Introduction}

Bisphosphonate-related osteonecrosis of the jaw (BRONJ) is a complicated adverse effect of treatment with bisphosphonates (BF), especially in patients undergoing oncology therapeutics. Some characteristics of this condition have been discovered and elucidated, but the pathogenesis is still uncertain (Allen and Burr, 2009).

The main studied mechanisms of BRONJ involve inhibitory effects of $\mathrm{BF}$ on bone turnover and angiogenesis. However, these purported mechanisms per se do not adequately explain the pathogenesis of BRONJ (Allen and Burr, 2009). BF have anti-angiogenic and antivasculogenic effects in vitro and in vivo (Ziebart et al, 2011; Misso et al, 2012), and this could contribute to the deficient prognosis of BRONJ (Lescaille et al, 2014). However, experimental murine models are not consistent with an association between BRONJ and the inhibition of vascularization or vascular proliferation markers (Sonis et al, 2009; Aguirre et al, 2010; Kobayashi et al, 2010; Marino et al, 2012).

On the other hand, infection is strongly associated with BRONJ, and antimicrobial approaches are generally utilized by dentistry clinics in association with surgical debridement. Although BF increase the adhesion of bacteria to the hydroxyapatite bone (Ganguli et al, 2005; Kobayashi et al, 2010), the isolated use of antimicrobial agents without removal of necrotic bone does not promote healing of BRONJ (Hoefert and Eufinger, 2011). The participation of infection in the pathogenesis of BRONJ has not been observed in any experimental model addressing 
this parameter (Sonis et al, 2009; Kobayashi et al, 2010; Maahs et al, 2011; Conte Neto et al, 2013). Despite the use of antimicrobial agents shows conflicting efficacy in the modification of serum and the local microbial profile of patients with BRONJ (Ji et al, 2012), why does antibiotic prophylaxis seems to be an acceptable option to prevent BRONJ in patients treated with high doses of BF (Montefusco et al, 2008; )?

Lopez-Jornet et al (2011) did not observe a relationship between BRONJ and infection, but the authors reported that infected animals had intense inflammatory infiltrated in exodontic locations, implying the development of BRONJ. Acute inflammation induces osteocyte apoptosis and inhibits the vitality and activity of osteoblasts (Gilbert et al, 2000; Cheung et al, 2011; Huang et al, 2011; Kawai et al, 2012). Proinflammatory cytokines also induce osteoclastogenesis (Assuma et al, 1998) and increase important modulators of the vitality of bone cells such as reactive oxygen species (ROS) (Halleen et al, 1999; Wimalawansa, 2010; Almeida and O'Brien, 2013).

Several experimental models (Sonis et al, 2009; AliErdem et al, 2011; López-Jornet et al, 2011; Maahs et al, 2011; Marino et al, 2012) and clinical studies (Lesclous et al, 2009) have demonstrated associations between inflammation and BRONJ. BF increase production of acute inflammatory mediators in vitro (Muratsu et al, 2013) and in vivo (Norton et al, 2012) and modify the immunological and cellular profile of patients undergoing chronic treatment (Rossini et al, 2012; Welton et al, 2013). Therefore, a consistent characterization of the immune and cellular profile of BRONJ has not been described (Vasconcelos et al, 2012).

Thus, the aim of this study was to conduct histomorphometric and immunohistochemical studies to characterize the cellular profile and immunoreactivity of certain chemical mediators.

\section{Materials and methods}

\section{Animals, doses, and experimental protocols}

Male Wistar rats $(n=6-7)$ were treated (three consecutive weeks) with intravascular (penile access) saline or zoledronic acid (ZA, molar mass = $290.1)$ at $0.04, \quad\left(1.4 \times 10^{-7} \mathrm{~mol} \mathrm{~kg}^{-1}\right), \quad 0.20 \mathrm{mg} \mathrm{kg}^{-1}\left(6.9 \times 10^{-6}\right.$ $\mathrm{mol} \mathrm{kg} \mathrm{kg}^{-1}$ ), and $1.00 \mathrm{mg} \mathrm{kg}^{-1}\left(3.4 \times 10^{-5} \mathrm{~mol} \mathrm{~kg}^{-1}\right)$ (days 00, 07, 14, respectively). Four weeks after the last infusion of ZA or saline (day 42), the first left inferior molar was extracted (using Hollemback $3 \mathrm{~s}$ and Lecron Zalle spatulas). During the following week (day 49), an additional ZA dose was infused. The animals were euthanized on the 70th experimental day, and their hemimandibles were fixed in neutral formalin $10 \%$ (Silva et al, 2015).

The approval for experimental use of laboratory animals was obtained from the local Ethics Committee on Animal Use (CEUA, former CEPA) (protocol 26/2013) and is in compliance with the Federal Law No. 11794 of October 8, 2008, and the Decree $\mathrm{n}^{\circ}$ 6689, July 15, 2009, that regulated the law in 11794 , available from http: www. planalto.gov.brccivil03Ato2007-20102008LeiL11794.htm.

\section{Histomorphometric and histochemical analysis}

After decalcification (ethylenediaminetetraacetic acid 10\%, $\mathrm{pH} 7.3$ ), microscopic slides $(4 \mu \mathrm{m})$ were prepared (conventional hematoxylineosin (HE) method) and qualitatively and histomorphometrically analyzed. Afterward, ten microscopic fields (400x) were used for counting of viable and empty osteocyte lacunae, total osteoclasts, viable and apoptotic osteoclasts, and polymorphonuclear neutrophil cells (Yamashita et al, 2011; Shaker et al, 2013).

Hydrated tissue sections $(4 \mu \mathrm{m})$ were immersed in $0.1 \%$ toluidine blue solution (in $0.9 \%$ sodium chloride) per 60 s for histochemical assessment (Gurgel et al, 2013) and mast cell counting using the same methodology (Shaker et al, 2013).

\section{Immunohistochemical analysis}

After deparaffinization and rehydration, the tissue sections $(2.5 \mu \mathrm{m})$ were also submitted to immunohistochemical assessment. Antigenic recovery was performed by heating in citrate $\mathrm{pH} 6.0$ solution. After cooling, the slides were submitted to peroxidase blocking with $\mathrm{H}_{2} \mathrm{O}_{2} 3 \%$ solution diluted in PBS (phosphate-buffered saline) or with methanol solution according to the antibody's specificity $(30 \mathrm{~min})$.

After protein blocking (albumin) $(1 \mathrm{~h})$, we performed incubation with primary antibody CD68 (Dako ${ }^{\circledR}$, Dopenhage, Denmark), tumor necrosis factor-alpha (TNF- $\alpha) \quad\left(\right.$ Abcam $^{\circledR}$, Cambridge, UK), IL (interleukin)-1 $\beta$ $\left(\right.$ Abcam $\left.^{\circledR}\right)$, inducible nitric oxide synthase (iNOS) $\left(\right.$ Abcam $\left.^{\circledR}\right)$, nuclear factor-kappa B (NF-kB) (SantaCruz ${ }^{\circledR}$, Finnell Street Dallas, Texas, USA), or IL-18 binding protein (IL-18 bp) $\left(\right.$ SantaCruz $\left.{ }^{\circledR}\right)$ using the dilutions and times shown in Table 1.

Envision System Plus-HRP $\left(\right.$ Dako $^{\circledR}$ ) (ready to use), Simple Stain Rat MAX PO (Multi) Universal Immuno-peroxidase Polymer (anti-mouse and anti-rabbit) (Histofine ${ }^{\circledR}$ ) (ready to use) or secondary biotinylated antirabbit polyclonal IgG and $\mathrm{ABC}$ (avidin-biotin-peroxidase) System (SantaCruz Biotechnology ${ }^{\circledR}$ ) (in diluted solutions) were utilized for the secondary antibody incubation. The visualization system used was 5,5diaminobenzidine tetrahydrochloride (DAB) (Dako ${ }^{\circledR}$ ) (Table 1).

Ten microscopic fields (400x) were used to count CD68 immunostaining mononuclear cells; cells exhibiting cytoplasmic positivity for TNF- $\alpha$, IL-1 $\beta$, iNOS, IL-18 bp, or NF-kB; and nuclear positivity for NF-kB in exodontic sites (Kim et al, 2012).

\section{Statistical analysis}

Kolmogorov-Smirnov normality testing was performed, and we utilized analysis of variance (ANOVA) followed by Tukey's post-test for group comparisons. The data were expressed as the mean and standard error of the mean (Mean \pm s.e.m.).

\section{Results}

\section{ZA-induced experimental BRONJ}

Twenty-eight days after tooth extraction, the saline solution group showed viable osteocytes and rare osteoclasts at the site of the exodontia's new bone (Figure 1a and 1e). The group treated with $0.04 \mathrm{mg} \mathrm{kg}^{-1} \mathrm{ZA}$ presented delayed deposition of osteoid; however, the development of BRONJ was not observed, nor were there any inflammations signs or damaged osteoclasts (Figure 1b and 1f). The dose of 0.20 (Figure $1 \mathrm{c}$ and $1 \mathrm{~g}$ ) or $1.00 \mathrm{mg} \mathrm{kg}^{-1}$ (Figure 1d and 1h) ZA led to large bone sequesters associated with intense inflammatory infiltrate, osteoclasts with intracytoplasmic vacuolization, nuclear hyperchromatism, and necrotic bone with irregular peripheral resorption. No signs of healing or deposition of the mineralized bone matrix were observed.

\section{Cellular profile of $\mathrm{BRONJ}$}

The groups treated with $0.20(32.5 \pm 1.1 \%)$ or 1.00 $(26.8 \pm 1.8 \%) \mathrm{mg} \mathrm{kg}^{-1} \mathrm{ZA}$ showed a statistical increase in percentage of empty osteocyte lacunae compared with the saline group $(6.4 \pm 1.0 \%)$ and $0.04(14.2 \pm 3.1 \%)$ $\mathrm{mg} \mathrm{kg}^{-1} \mathrm{ZA}$ groups $(P<0.001)$ (Figure 1).

The total osteoclast number was greater in these two groups. Groups treated with $0.20(31.4 \pm 7.9)$ or 1.00 $(39.0 \pm 3.5) \mathrm{mg} \mathrm{kg}^{-1} \mathrm{ZA}$ had a higher osteoclast number 
Table 1 Parameters and methodologies of immunohistochemistry evaluation

\begin{tabular}{|c|c|c|c|c|c|c|c|c|c|}
\hline \multirow[b]{2}{*}{ Antibody } & \multirow[b]{2}{*}{ Production } & \multirow{2}{*}{$\begin{array}{l}\text { Antigenic } \\
\text { recuperation } \\
\text { Methodology } \\
\text { (solution) }\end{array}$} & \multirow{2}{*}{$\begin{array}{l}\text { Peroxidase blocking } \\
\mathrm{H}_{2} \mathrm{O}_{2} \text { concentration } \\
\text { (solution dilution) }\end{array}$} & \multicolumn{2}{|c|}{ Primary antibody } & \multicolumn{2}{|c|}{ Secondary antibody } & \multirow[b]{2}{*}{$\begin{array}{l}\text { Revelation } \\
\text { System } \\
\text { (time) }\end{array}$} & \multirow[b]{2}{*}{ Cell count } \\
\hline & & & & Dilution & $\begin{array}{l}\text { Time of } \\
\text { incubation }\end{array}$ & $\begin{array}{c}\text { System and/or } \\
\text { dilution (Production) }\end{array}$ & $\begin{array}{l}\text { Time of } \\
\text { incubation }\end{array}$ & & \\
\hline CD68 & Dako $^{\circledR}$ & $\begin{array}{l}\text { Heat } \\
\text { (Citrate } \\
\text { pH 6.0) }\end{array}$ & $\mathrm{H}_{2} \mathrm{O}_{2} 3 \%$ (PBS) & $1: 500$ & Overnight & $\begin{array}{l}\text { Envision System } \\
\text { Plus-HRP }\left(\text { Dako }^{\circledR}\right)\end{array}$ & $30^{\prime}$ & $\mathrm{DAB}\left(5^{\prime}\right)$ & $\begin{array}{r}\text { Mononuclear- } \\
\text { positive cells }\end{array}$ \\
\hline TNF- $\alpha$ & Abcam $^{\circledR}$ & $\begin{array}{l}\text { Heat (Citrate } \\
\text { pH 6.0) }\end{array}$ & $\mathrm{H}_{2} \mathrm{O}_{2} 3 \%$ (PBS) & $1: 50$ & $1 \mathrm{~h}$ & $\begin{array}{l}\text { Universal } \\
\text { Immuno-peroxidase } \\
\text { Polymer (Histofine }{ }^{\circledR} \text { ) }\end{array}$ & $30^{\prime}$ & $\mathrm{DAB}\left(5^{\prime}\right)$ & Positive cells \\
\hline IL- $1 \beta$ & Abcam $^{\circledR}$ & $\begin{array}{l}\text { Heat } \\
\text { (Citrate } \\
\text { pH 6.0) }\end{array}$ & $\mathrm{H}_{2} \mathrm{O}_{2} 3 \%$ (PBS) & $1: 100$ & $1 \mathrm{~h}$ & $\begin{array}{l}\text { Universal } \\
\text { Immuno-peroxidase } \\
\text { Polymer (Histofine }{ }^{\circledR} \text { ) }\end{array}$ & $30^{\prime}$ & $\mathrm{DAB}\left(5^{\prime}\right)$ & Positive cells \\
\hline iNOS & Abcam $^{\circledR}$ & $\begin{array}{l}\text { Heat } \\
\text { (Citrate } \\
\mathrm{pH} 6.0)\end{array}$ & $\mathrm{H}_{2} \mathrm{O}_{2} 3 \%$ (PBS) & $1: 200$ & Overnight & $\begin{array}{l}\text { Universal } \\
\text { Immuno-peroxidase } \\
\text { Polymer (Histofine }{ }^{\circledR} \text { ) }\end{array}$ & $30^{\prime}$ & $\mathrm{DAB}\left(5^{\prime}\right)$ & Positive cells \\
\hline NF-kB & SantaCruz $^{\circledR}$ & $\begin{array}{l}\text { Heat (Citrate } \\
\text { pH 6.0) }\end{array}$ & $\begin{array}{l}\mathrm{H}_{2} \mathrm{O}_{2} 3 \% \\
\text { (Methanol) }\end{array}$ & $1: 200$ & Overnight & $\begin{array}{l}\text { Secondary biotinylated } \\
\text { anti-rabbit } \\
\text { IgG } 1: 500+ \\
\text { ABC System } \\
\left(\text { SantaCruz }^{\circledR}\right)\end{array}$ & $30^{\prime}+30^{\prime}$ & DAB $\left(10^{\prime \prime}\right)$ & $\begin{array}{l}\text { Positive cells } \\
\text { in cytoplasm } \\
\text { and nucleus }\end{array}$ \\
\hline IL-18 bp & SantaCruz $^{\circledR}$ & $\begin{array}{l}\text { Heat } \\
\text { (Citrate } \\
\text { pH 6.0) }\end{array}$ & $\mathrm{H}_{2} \mathrm{O}_{2} 3 \%(\mathrm{PBS})$ & $1: 100$ & Overnight & $\begin{array}{l}\text { Secondary biotinylated } \\
\text { anti-rabbit } \\
\text { IgG } 1: 200+ \\
\text { ABC System } \\
\left(\text { SantaCruz }^{\circledast}\right)\end{array}$ & $30^{\prime}+30^{\prime}$ & DAB $\left(45^{\prime \prime}\right)$ & $\begin{array}{l}\text { Positive } \\
\text { cells }\end{array}$ \\
\hline
\end{tabular}

TNF- $\alpha$, Tumor necrosis factor-alpha; IL-1 $\beta$, interleukin-1beta; iNOS, induced nitric oxide synthase; NF-kB, nuclear factor-kappa B; IL-18 bp, interleukin-18 binding protein; HRP, horseradish peroxidase; $\mathrm{ABC}$, avidin-biotin-complex; DAB, 5,5-diaminobenzidine tetrahydrochloride.

than the saline group $(6.3 \pm 1.3)(P=0.003)$. There was no significantly difference between the saline and $0.04 \mathrm{mg} \mathrm{Kg}^{-1}(20.5 \pm 3.2)$ groups. This augmentation was accompanied by the number of osteoclasts with apoptotic signs. Both groups with $0.20(87.4 \pm 2.0 \%)$ and $1.00(79.8 \pm 1.1 \%) \mathrm{mg} \mathrm{kg}^{-1} \mathrm{ZA}$ showed a higher percentage of apoptotic osteoclasts than the saline $(5.0 \pm$ $5.0 \%)$ or $0.04 \mathrm{mg} \mathrm{Kg}^{-1}(11.8 \pm 5.7 \%)$ group $(P<0.001)$ (Figure 1).

Regarding the cellular inflammatory profile, an increase in number of polymorphonuclear neutrophils was observed in the groups treated with $0.20(213.3 \pm 122.4)$ or $1.00 \mathrm{mg} \mathrm{kg}^{-1}(255.0 \pm 45.0) \mathrm{ZA}$ compared with the saline $(0.0 \pm 0.0)$ and $0.04 \mathrm{mg} \mathrm{kg}^{-1} \mathrm{ZA}$ groups $(9.5 \pm 8.3)$ $(P=0.009)$. The number of mononuclear CD68-positive cells was significantly higher in the $0.20(205.0 \pm 31.3)$ and $1.00(240.7 \pm 11.3) \mathrm{mg} \mathrm{kg}^{-1} \mathrm{ZA}$ groups than in the $0.04 \mathrm{mg} \mathrm{Kg}^{-1} \mathrm{ZA}(86.5 \pm 18.7)$ or saline $(66.7 \pm 5.8)$ group $(P<0.001)$. There was no statistically significant difference in mast cell number among the groups (saline: $30.5 \pm 6.7,0.04 \mathrm{mg} \mathrm{kg}^{-1} \mathrm{ZA}: 30.3 \pm 7.0,0.20 \mathrm{mg} \mathrm{kg}^{-1}$ $\left.\mathrm{ZA}: \quad 34.0 \pm 5.93, \quad 1.00 \mathrm{mg} \mathrm{kg}^{-1} \quad \mathrm{ZA}: \quad 29.8 \pm 3.7\right)$ $(P=0.957)$ (Figure 1).

\section{Immune inflammatory profile of BRONJ}

There was a significant increase in cells exhibiting immunostaining for Th1 inflammatory markers (Figure 2).

The immunostaining for TNF- $\alpha$ was greater in the groups treated with $0.20(3312.0 \pm 180.8)$ or 1.00 $(2912.0 \pm 179.7) \mathrm{mg} \mathrm{kg}^{-1} \mathrm{ZA}$ than in the saline group $(1811.0 \pm 145.0)(P=0.001)$. However, there was no difference between the $0.04(2325.0 \pm 141.8) \mathrm{mg} \mathrm{kg}^{-1} \mathrm{ZA}$ and saline groups (Figure 2).
The number of positive cells for IL- $1 \beta$ was higher in the $\quad 0.20 \quad(5386.0 \pm 459)$ and $1.00 \quad(6359 \pm 512.4)$ $\mathrm{mg} \mathrm{kg}^{-1}$ groups than in the saline $(2695.0 \pm 104.2)$ group $(P=0.001)$. Nevertheless, a difference between the saline and $0.04 \mathrm{mg} \mathrm{Kg}^{-1}(3589.0 \pm 477.6)$ groups was not observed. Similarly, positive cells for iNOS were augmented in the $0.20(5436.0 \pm 827.5)$ and $1.00(6356.0 \pm$ 523.7) $\mathrm{mg} \mathrm{kg}^{-1} \mathrm{ZA}$ groups compared with the saline $(933.3 \pm 396.1)$ or $0.04 \mathrm{ZA} \mathrm{mg} \mathrm{Kg}{ }^{-1}(1825.0 \pm 159.4)$ group $(P<0.001)$ (Figure 2).

Cytoplasmic and nuclear positivity for NF-kB were higher in the groups with BRONJ. In the cytoplasm, the groups treated with $0.20 \mathrm{mg} \mathrm{Kg}^{-1} \mathrm{ZA}(576.5 \pm 86.7)$ or $1.00 \mathrm{mg} \mathrm{kg}^{-1} \mathrm{ZA}(597.7 \pm 135.6)$ showed elevated numbers of cells exhibiting positivity compared with the saline group $(52.5 \pm 45.5) \quad(P=0.011)$. There was no difference in immunostaining for cytoplasmic NF-kB between the saline and $0.04 \mathrm{mg} \mathrm{Kg}^{-1} \mathrm{ZA}(157.0 \pm 77.7)$ groups. Nuclear staining for NF-kB was significantly increased in the groups treated with $0.20 \mathrm{mg} \mathrm{kg}^{-1} \mathrm{ZA}(84.3 \pm 9.9)$ or $1.00 \mathrm{mg} \mathrm{Kg}^{-1}$ ZA $(285.7 \pm 115.4) \quad$ compared with the saline group $(8.7 \pm 4.3)(P=0.006)$. There was no significant difference between the saline group and the $0.04 \mathrm{mg} \mathrm{Kg}^{-1}(19.7 \pm 7.1)$ or $0.20 \mathrm{mg} \mathrm{Kg}^{-1} \mathrm{ZA}(84.3 \pm 9.9)$ groups (Figure 2$)$.

Immunostaining for IL-18 bp was increased in the group treated with $0.04 \mathrm{mg} \mathrm{kg}^{-1} \mathrm{ZA}(418.6 \pm 119.1)$ compared with the saline group $(12.5 \pm 6.6)$. A difference between the groups with $0.04 \mathrm{mg} \mathrm{kg}^{-1} \mathrm{ZA}$ and $0.20 \mathrm{mg} \mathrm{kg}^{-1} \mathrm{ZA}(203.3 \pm 93.5)$ was not observed. Nevertheless, there was a significant decrease in positive cells for IL-18 bp in the group treated with $1.00 \mathrm{mg} \mathrm{kg}^{-1} \mathrm{ZA}(105.8 \pm 31.7)$ compared with the 


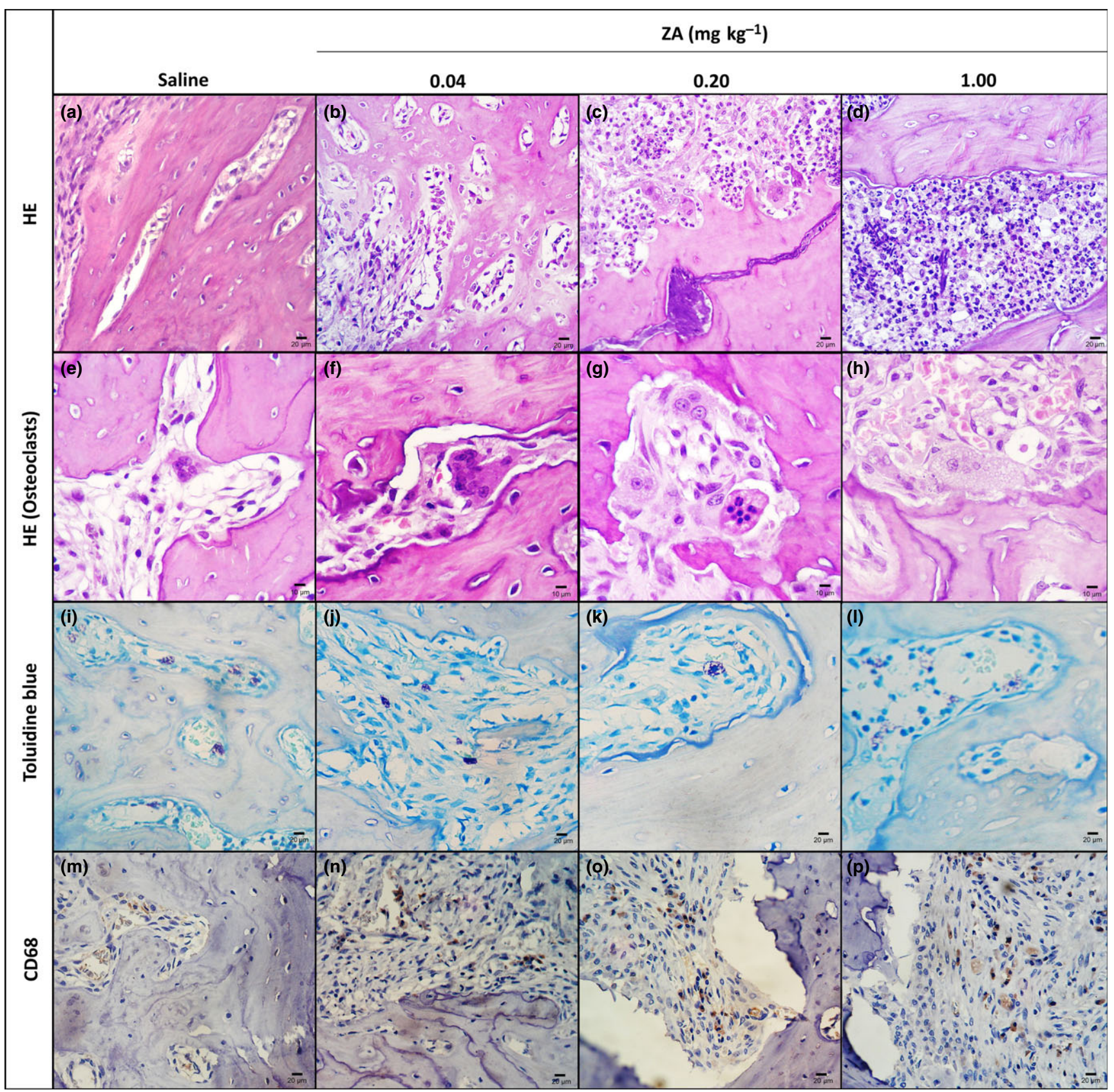

Figure 1 Cellular profile of BRONJ showing reduction in bone formation and viable osteocytes $(\mathbf{a}-\mathbf{d})$, increased number of osteoclasts $(\mathbf{e}-\mathbf{h})$ with apoptotic signs, no alteration in mast cells $(\mathbf{i}-\mathbf{l})$, and increased number of mononuclear CD68-positive cells $(\mathbf{m}-\mathbf{p})$ dose dependently $(400 \times)$

$0.04 \mathrm{mg} \mathrm{kg}^{-1}$ ZA $(418.6 \pm 119.1)$ group $(P=0.005)$ (Figure 2).

\section{Discussion}

The participation of inflammation in BRONJ has been described since the first reports and research on the disease. However, the focus of the studies has been centered on the role of bacterial infection (Hinson et al, 2014). Although infection is importantly associated with BRONJ, antimicrobial therapy has a low level of success compared with the surgical approach in the treatment of this condition (Rupel et al, 2014).
More than $81.6 \%$ of cases of BRONJ are associated with inflammation. This is a value discreetly higher than the association between BRONJ and infection (80.3\%) (Hinson et al, 2014). In experimental models with rats, BRONJ was not associated with infection but with intense inflammation (López-Jornet et al, 2011). Thus, immune dysregulation may play a key role in BRONJ pathogenesis.

BRONJ is directly associated to proinflammatory condition. This is a dose-dependent pathology associated with leukocytosis and changes of erythrocytes (Silva et al, 2015). It is demonstrated that low doses $\left(0.0225 \mathrm{mg} \mathrm{kg}^{-1}\right)$ of ZA not induce BRONJ (Sonis et al, 2009) despite 


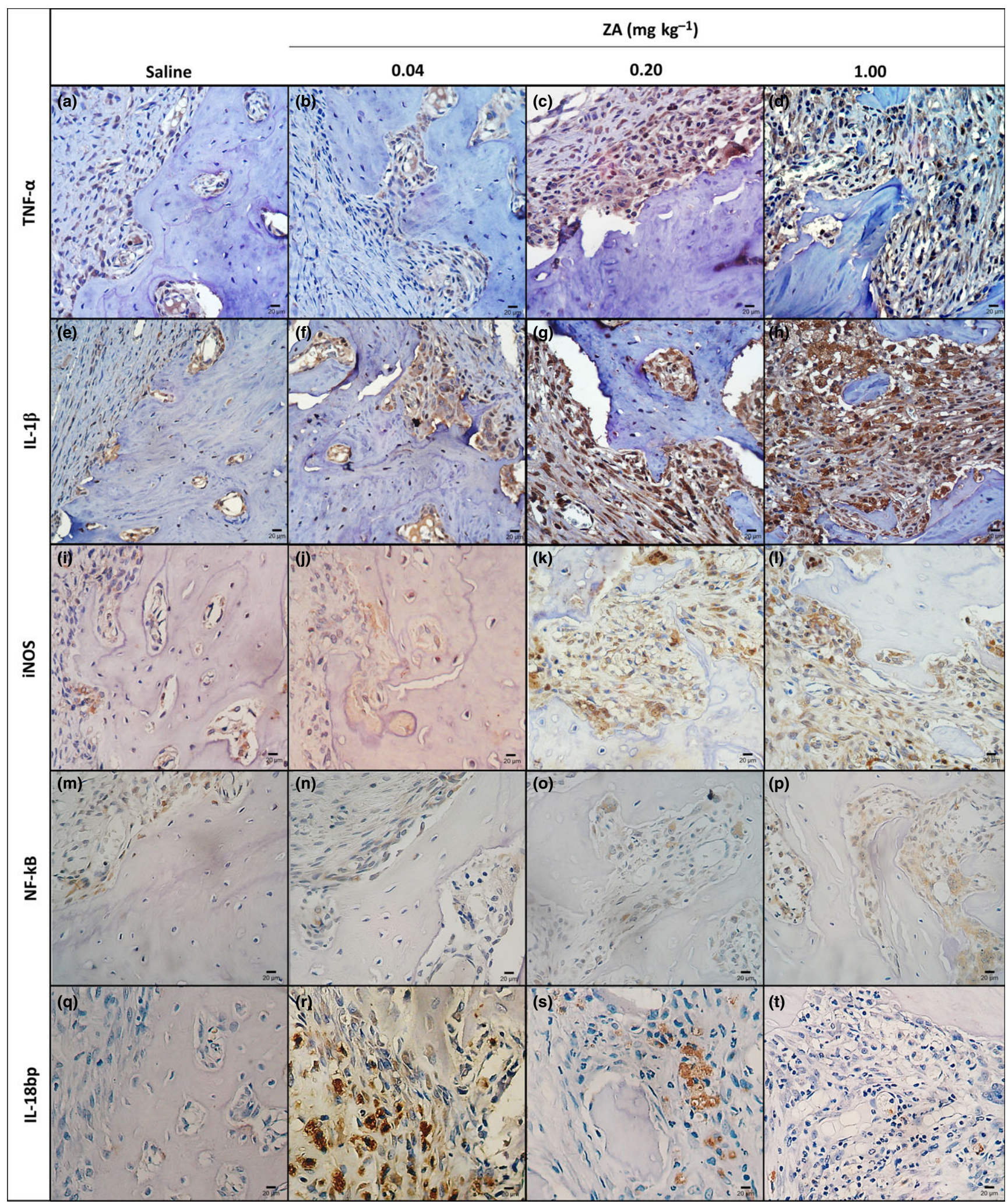

Figure 2 Cytokine profile showing dose-dependent increases in the number of TNF- $\alpha$ (a-d), IL-1 $\beta$ (e-h), iNOS (i-I), and NF-kB (nucleus and cytoplasm) (m-p)-positive cells. An increase in the number of IL-18 bp-positive cells was seen in the $0.04 \mathrm{mg} \mathrm{kg}^{-1} \mathrm{ZA}$ group in comparison with the saline group, and a significant reduction was seen with a higher ZA dose $(\mathbf{q}-\mathbf{t})(400 \times)$

proinflammatory stimulus is added (Marino et al, 2012). In vivo (classical peritonitis experiment) amino-bisphosphonates acutely upregulate proinflammatory cytokine production mediated by mast cells and the IL-1 receptor (IL-1R) (Norton et al, 2012). This cytokine, IL-1, is directly associated with BRONJ in the salival and gingival 

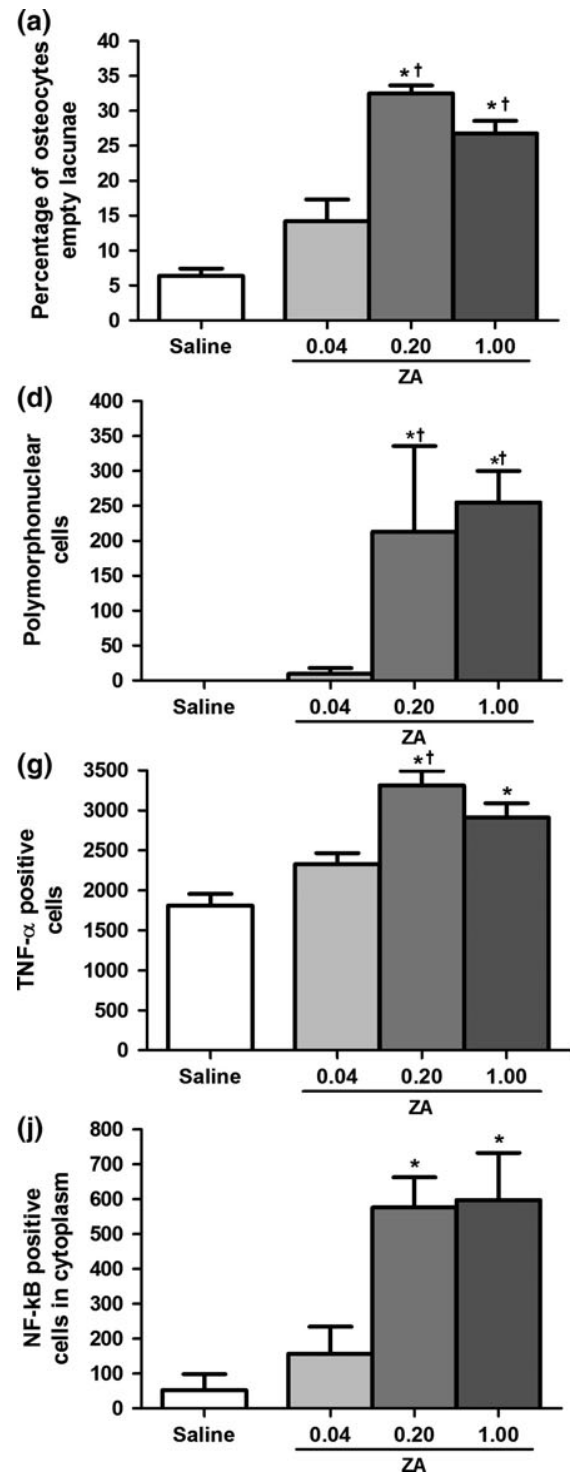

(b)

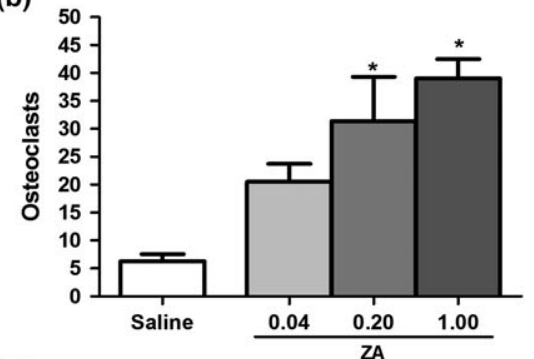

(e)
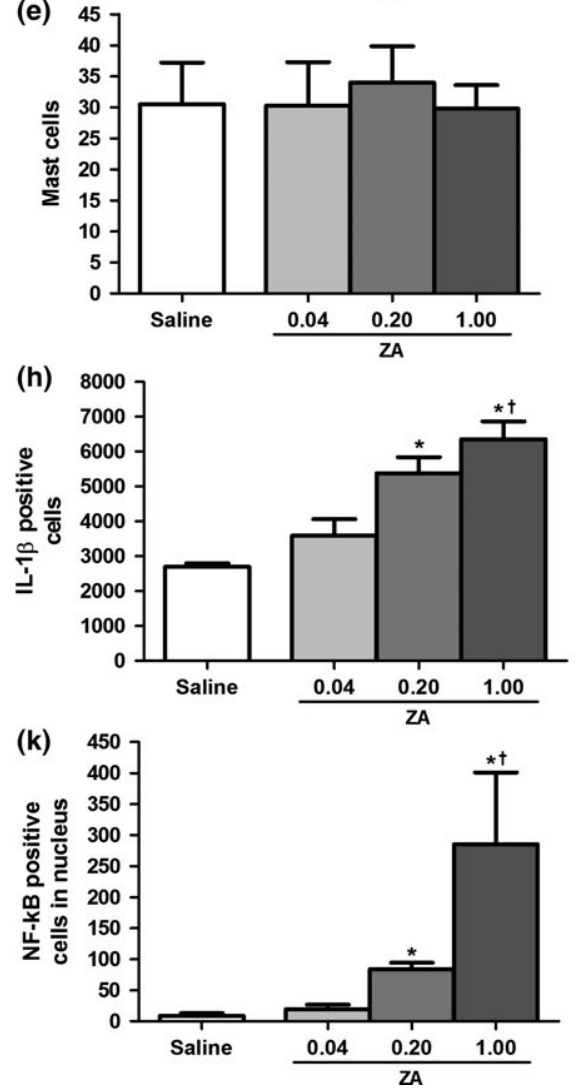
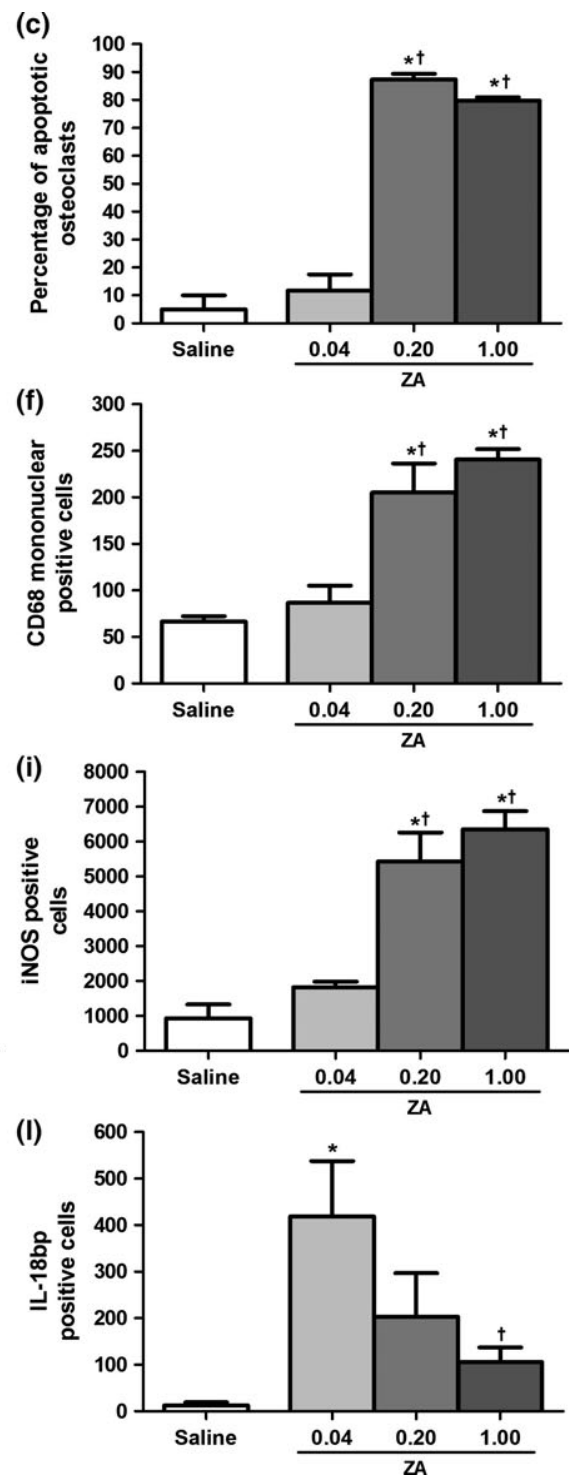

Figure 3 Cellular and cytokine profile analyses. ${ }^{*} P<0.05$ versus saline, $\dagger P<0.05$ versus $0.04 \mathrm{mg} \mathrm{kg}^{-1} \mathrm{ZA}$ (ANOVA test followed by Tukey's posttest; Mean \pm s.e.m.)

fluid of patients (Bagan et al, 2013; Tsao et al, 2013) such as oxidative stress markers (Bagan et al, 2014).

In this experimental model, mast cells were not augmented in number (Figure 3). In bone, these cells can release proinflammatory cytokines by degranulation, but they are not necessarily increased in number (Huang et al, 2013). On the other hand, there were increases in some acute inflammatory markers such as TNF- $\alpha$, IL- $1 \beta$, iNOS, NF-kB activation (Figure 2), and numbers of neutrophils and macrophages (positive CD68 cells) but not of mast cells. ZA is a strong myelotoxic drug (Kuiper et al, 2012), but it increases cytokine production by macrophages through NF-kB activation (Muratsu et al, 2013).

TNF- $\alpha$ (Cheung et al, 2011), IL-1 $\beta$ (Bonewald, 2004; Bakker et al, 2009), and high oxidative stress from iNOS activity (Almeida and O'Brien, 2013) modulate the increase in osteocyte apoptosis. The formation of apoptotic bodies in osteocytes is a stimulus for the recruitment and activation of macrophages and osteoclasts (Kogianni et al,
2008), which are important scavenger cells involved in recognition of these apoptotic bodies for phagocytosis and empty bone resorption (Oizumi et al, 2009; Harre et al, 2012).

In this study, the increase in empty osteocyte lacunae was accompanied by increases in macrophages, osteoclasts, TNF- $\alpha$, IL- $1 \beta$, and iNOS-positive cells, supporting these previous studies. However, as ZA strongly induces osteoclast apoptosis, interrupting physiological bone resorption (Oizumi et al, 2009), there was also an increase in apoptotic osteoclasts.

$\mathrm{ZA}$ and other BF (alendronate) inhibit TRAP function and infiltration of CD68-positive cells in bone (Xiong et al, 2010; Yamashita et al, 2011). However, BRONJ is a chronic condition strongly associated with tooth extraction. After a tooth is extracted, it increases TNF- $\alpha$ expression, osteoclastogenesis, bone resorption, and bone matrix deposition occur with a reduction in proinflammatory cytokines to basal levels after 10 days (Kim et al, 2012). 
Nevertheless, the osteoclast apoptosis induced by ZA adds proinflammatory effects in connective tissue cells and seems to perpetuate and upregulate these proinflammatory mediators, leading to deregulated osteocyte apoptosis (Bonewald, 2004; Bakker et al, 2009; Cheung et al, 2011; Almeida and O'Brien, 2013), macrophage infiltration and activation (Kogianni et al, 2008; Harre et al, 2012), and more cytokine production (Muratsu et al, 2013).

Conversely, IL-18 bp shows an inverse association with the dose-dependent proinflammatory effects of ZA in bone of rats submitted to tooth extraction (Figure 2). IL-18 bp inhibits IL-8, a chemokine involved in the migration of neutrophils (Novick et al, 1999), which is a cellular group that can increase cytokine levels and cause damage to some tissues when it is augmented in number (LimaJúnior et al, 2012).

IL-18 bp has antineutrophil effects and modulates the immune response. This mediator is a member of a binding protein family with anti-inflammatory and anti-osteoclastogenic effects, such as OPG. IL-18 bp prevents binding to the IL-18R receptor (31\% similarity with IL-1R (Nakanishi et al, 2001), a receptor directly involved in BRONJ patients (Bagan et al, 2013) that mediates the immune transition of the Th1/ Th2 response (Novick et al, 1999). In Th2 responses, osteoclastogenesis and bone resorption are inhibited (Horwood et al, 2001; Yamada et al, 2002; Morita et al, 2010). This process can attenuate bone diseases such as periodontitis (Orozco et al, 2007) and decrease inflammatory mediators and high oxidative stress (Shaker et al, 2013).

IL-18 bp is produced by plasma cells and B lymphocytes. It inhibits NF-kB activity (Novick et al, 1999) by interrupting the interaction between IL-18 and IL-18R. Afterward, there is a breakdown activation cascade of MyD88, IRAK1 and IRAK2, TRAF6, NIK, and IKK and a dissociation of IkB and NF-kB in the cytoplasm (Nakanishi et al, 2001). This is the major mechanism of ZAinduced proinflammatory cytokine production in macrophages (Muratsu et al, 2013).

There are no experimental models demonstrating an association between IL-18 and IL-18 bp in BRONJ. However, the late mediators that modulate the immune response seem to participate in BRONJ pathogenesis, such as overexpression of IL-17 (Li et al, 2013). IL-17 is a proinflammatory cytokine related to increases in some others mediators such as IL- $1 \beta$, TNF- $\alpha$, and iNOS produced by macrophages and other connective tissue cells (Lee, 2013). Other experimental models showed no alterations in inflammatory bone markers (RANK/ RANKL/OPG axis) in animals treated with ZA (Vasconcelos et al, 2012). Thus, ZA seems to modify most strongly general inflammatory markers (TNF- $\alpha, \mathrm{IL}-1 \beta$, IL-6 (Muratsu et al, 2013), and IL-17 (Li et al, 2013)) than inflammatory bone markers. Accordingly, the role of inflammatory cells and their general mediators seems to constitute a possible direction for understanding the pathogenesis of BRONJ.

In conclusion, BRONJ is characterized by increases in empty osteocyte lacunae; osteoclast numbers (total and apoptotic); polymorphonuclear neutrophils; CD68 mononuclear-positive cells; immunostaining for TNF- $\alpha$, IL-1 $\beta$, iNOS, and NF-kB (nuclear and cytoplasmic) but not mast cells. BRONJ is also inversely associated with cells exhibiting IL-18 bp. More studies are needed to show that BRONJ is dependent on immune modulation.

\section{Author contributions}

Paulo Goberlânio de Barros Silva and Camila Carvalho de Oliveira performed experiments, statistical analysis, and writing of the paper. Luiz André Cavalcante Brizeno and Deysi Viviana Tenazoa Wong were responsible for histochemical and immunohistochemical reactions. Roberto César Pereira Lima Júnior and Romélia Pinheiro Gonçalves were responsible for the pharmacological study design, review of the statistical analysis, and writing of the paper. Fabrício Bitú Sousa and Mário Rogério Lima Mota were responsible for the pathological study design, review text, and writing of the paper. Ronaldo de Albuquerque Ribeiro and Ana Paula Negreiros Nunes Alves designed the model, guided experiments, and reviewed the text. All the authors read and approved the final version.

\section{References}

Aguirre JI, Altman MK, Vanegas SM et al (2010). Effects of alendronate on bone healing after tooth extraction in rats. Oral Dis 16: 674-685.

Ali-Erdem M, Burak-Cankaya A, Cemil-Isler S et al (2011). Extraction socket healing in rats treated with bisphosphonate: animal model for bisphosphonate related osteonecrosis of jaws in multiple myeloma patients. Med Oral Patol Oral Cir Bucal 16: e879-e883.

Allen MR, Burr DB (2009). The pathogenesis of bisphosphonate-related osteonecrosis of the jaw: so many hypotheses, so few data. J Oral Maxillofac Surg 67: 61-70.

Almeida M, O'Brien CA (2013). Basic Biology of Skeletal Aging: role of Stress Response Pathways. J Gerontol A Biol Sci Med Sci 68: 1197-1208.

Assuma R, Oates T, Cochran D et al (1998). IL-1 and TNF antagonists inhibit the inflammatory response and bone loss in experimental periodontitis. J Immunol 160: 403-409.

Bagan J, Sheth CC, Soria JM et al (2013). Bisphosphonatesrelated osteonecrosis of the jaws: a preliminary study of salivary interleukins. J Oral Pathol Med 42: 405-408.

Bagan J, Sáez GT, Tormos MC et al (2014). Oxidative stress in bisphosphonate-related osteonecrosis of the jaws. J Oral Pathol Med 43: 371-377.

Bakker AD, Silva VC, Krishnan R et al (2009). Tumor necrosis factor alpha and interleukin-1beta modulate calcium and nitric oxide signaling in mechanically stimulated osteocytes. Arthritis Rheum 60: 3336-3345.

Bonewald LF (2004). Osteocyte biology: its implications for osteoporosis. J Musculoskelet Neuronal Interact 4: 101-104.

Cheung WY, Liu C, Tonelli-Zasarsky RM et al (2011). Osteocyte Apoptosis Is Mechanically Regulated and Induces Angiogenesis In Vitro. J Orthop Res 29: 523-530.

Conte Neto N, Spolidorio LC, Andrade CR et al (2013). Experimental development of bisphosphonate-related osteonecrosis of the jaws in rodents. Int J Exp Pathol 94: 65-73.

Ganguli A, Steward C, Butler SL et al (2005). Bacterial adhesion to bisphosphonate coated hydroxyapatite. J Mater Sci Mater Med 16: 283-287.

Gilbert L, He X, Farmer P et al (2000). Inhibition of osteoblast differentiation by tumor necrosis factor-alpha. Endocrinology 141: 3956-3964. 
Gurgel JA, Lima-Júnior RC, Rabelo CO et al (2013). Amitriptyline, clomipramine, and maprotiline attenuate the inflammatory response by inhibiting neutrophil migration and mast cell degranulation. Rev Bras Psiquiatr 35: 387-392.

Halleen JM, Räisänen S, Salo JJ et al (1999). Intracellular fragmentation of bone resorption products by reactive oxygen species generated by osteoclastic tartrate-resistant acid phosphatase. J Biol Chem 274: 22907-22910.

Harre U, Keppeler H, Ipseiz N et al (2012). Moonlighting osteoclasts as undertakers of apoptotic cells. Autoimmunity 45: 612619.

Hinson AM, Smith CW, Siegel ER et al (2014). Is bisphosphonate-related osteonecrosis of the Jaw an Infection? a histological and microbiological ten-year summary. Int J Dent $\mathbf{4 5 2 7 3}$ : 7.

Hoefert S, Eufinger H (2011). Relevance of a Prolonged Preoperative Antibiotic Regime in the Treatment of BisphosphonateRelated Osteonecrosis of the Jaw. J Oral Maxillofac Surg 69: 362-380.

Horwood NJ, Elliott J, Martin TJ et al (2001). IL-12 alone and in synergy with IL-18 inhibits osteoclast formation in vitro. J Immunol 166: 4915-4921.

Huang $\mathrm{H}$, Zhao $\mathrm{N}$, $\mathrm{Xu} \mathrm{X}$ et al (2011). Dosespecific effects of tumor necrosis factor alpha on osteogenic differentiation of mesenchymal stem cells. Cell Prolif 44: 420-427.

Huang S, Lu F, Chen Y et al (2013). Mast cell degranulation in human periodontitis. J Periodontology 84: 248-255.

Ji X, Pushalkar S, Li Y et al (2012). Antibiotic effects on bacterial profile in osteonecrosis of the jaw. Oral Dis 18: 85-95.

Kawai VK, Stein CM, Perrien DS et al (2012). Effects of antitumor necrosis factor $\alpha$ agents on bone. Curr Opin Rheumatol 24: $576-585$.

Kim DJ, Cha JK, Yang C et al (2012). Changes in periodontium after extraction of a periodontally-involved tooth in rats. $J$ Periodontal Implant Sci 42: 158-165.

Kobayashi Y, Hiraga T, Ueda A et al (2010). Zoledronic acid delays wound healing of the tooth extraction socket, inhibits oral epithelial cell migration, and promotes proliferation and adhesion to hydroxyapatite of oral bacteria, without causing osteonecrosis of the jaw, in mice. J Bone Miner Metab 28: $165-175$.

Kogianni G, Mann V, Noble BS (2008). Apoptotic bodies convey activity capable of initiating osteoclastogenesis and localized bone destruction. J Bone Miner Res 23: 915-927.

Kuiper JW, Forster C, Sun C et al (2012). Zoledronate and pamidronate depress neutrophil functions and survival in mice. Br J Pharmacol 165: 532-539.

Lee Y (2013). The role of interleukin-17 in bone metabolism and inflammatory skeletal diseases. BMC Reports 46: 479-483.

Lescaille G, Coudert AE, Baaroun V et al (2014). Clinical study evaluating the effect of bevacizumab on the severity of zoledronic acid-related osteonecrosis of the jaw in cancer patients. Bone 58: 103-107.

Lesclous P, Abi Najm S, Carrel JP et al (2009). Bisphosphonateassociated osteonecrosis of the jaw: a key role of inflammation? Bone 45: 843-852.

Li Y, Xu J, Mao L et al (2013). Allogeneic mesenchymal stem cell therapy for bisphosphonate-related jaw osteonecrosis in swine. Stem Cells Dev 22: 2047-2056.

Lima-Júnior RC, Figueiredo AA, Freitas HC et al (2012). Involvement of nitric oxide on the pathogenesis of irinotecaninduced intestinal mucositis: role of cytokines on inducible nitric oxide synthase activation. Cancer Chemother Pharmacol 69: 931-942.

López-Jornet P, Camacho-Alonso F, Martínez-Canovas A et al (2011). Perioperative antibiotic regimen in rats treated with pamidronate plus dexamethasone and subjected to dental extraction: a study of the changes in the jaws. J Oral Maxillofac Surg 69: 2488-2493.

Maahs MP, Azambuja AA, Campos MM et al (2011). Association between bisphosphonates and jaw osteonecrosis: a study in Wistar rats. Head Neck 33: 199-207.

Marino KL, Zakhary I, Abdelsayed RA et al (2012). Development of a rat model of bisphosphonate-related osteonecrosis of the jaw (BRONJ). J Oral Implantol 38: 511-518.

Misso G, Porru M, Stoppacciaro A et al (2012). Evaluation of the in vitro and in vivo antiangiogenic effects of denosumab and zoledronic acid. Cancer Biol Ther 13: 1491-1500.

Montefusco V, Gay F, Spina F et al (2008). Antibiotic prophylaxis before dental procedures may reduce the incidence of osteonecrosis of the jaw in patients with multiple myeloma treated with bisphosphonates. Leuk Lymphoma 49: 2156-2162.

Morita Y, Kitaura H, Yoshimatsu M et al (2010). IL18 inhibits TNF-alpha-induced osteoclastogenesis possibly via a $\mathrm{T}$ cell-independent mechanism in synergy with IL12 in vivo. Calcif Tissue Int 86: 242-248.

Muratsu D, Yoshiga D, Taketomi T et al (2013). Zoledronic acid enhances lipopolysaccharide-stimulated proinflammatory reactions through controlled expression of SOCS1 in macrophages. PLoS One 8: e67906.

Nakanishi K, Yoshimoto T, Tsutsui H et al (2001). Interleukin18 regulates both Th1 and Th2 responses. Annu Rev Immunol 19: 423-474.

Norton JT, Hayashi T, Crain B et al (2012). Cutting edge: nitrogen bisphosphonate-induced inflammation is dependent upon mast cells and IL-1. J Immunol 188: 2977-2980.

Novick D, Kim SH, Fantuzzi G et al (1999). Interleukin-18 Binding Protein: a novel modulator of the Th1 cytokine response. Immunity 10: 127-136.

Oizumi T, Yamaguchi K, Funayama H et al (2009). Necrotic actions of nitrogen-containing bisphosphonates and their inhibition by clodronate, a non-nitrogen-containing bisphosphonate in mice: potential for utilization of clodronate as a combination drug with a nitrogen-containing bisphosphonate. Basic Clin Pharmacol Toxicol 104: 384-392.

Orozco A, Gemmell E, Bickel M et al (2007). Interleukin 18 and periodontal disease. J Dent Res 86: 586-593.

Rossini M, Adami S, Viapiana O et al (2012). Long-term effects of amino-bisphosphonates on circulating $\gamma \delta \mathrm{T}$ cells. Calcif Tissue Int 91: 395-399.

Rupel K, Ottaviani G, Gobbo M et al (2014). A systematic review of therapeutical approaches in bisphosphonates-related osteonecrosis of the jaw (BRONJ). Oral Oncol 5: 1049-1057.

Shaker O, Ghallab NA, Hamdy E et al (2013). Inducible nitric oxide synthase (iNOS) in gingival tissues of chronic periodontitis with and without diabetes: immunohistochemistry and RT-PCR study. Arch Oral Biol 58: 1397-1406.

Silva PGB, Ferreira AEC Jr, Barbosa MC et al (2015). Effect of different doses of zoledronic acid in establishing of bisphosphonate-related osteonecrosis. Arch Oral Biol 60: 1237-1245.

Sonis ST, Watkins BA, Lyng GD et al (2009). Bony changes in the jaws of rats treated with zoledronic acid and dexamethasone before dental extractions mimic bisphosphonate-related osteonecrosis in cancer patients. Oral Oncol 45: 164-172.

Tsao C, Darby I, Ebeling PR et al (2013). Oral health risk factors for bisphosphonate-associated jaw osteonecrosis. J Oral Maxillofac Surg 71: 1360-1366.

Vasconcelos AC, Berti-Couto SA, Azambuja AA et al (2012). Comparison of effects of clodronate and zoledronic acid on the repair of maxilla surgical wounds - histomorphometric, receptor activator of nuclear factor-kB ligand, osteoprotegerin, von Willebrand factor, and caspase-3 evaluation. J Oral Pathol Med 41: 702-712. 
Welton JL, Morgan MP, Martí S et al (2013). Monocytes and $\gamma \delta$ $\mathrm{T}$ cells control the acute-phase response to intravenous zoledronate: insights from a phase IV safety trial. J Bone Miner Res 28: 464-471.

Wimalawansa SJ (2010). Nitric oxide and bone. Ann N Y Acad Sci 1192: 391-403.

Xiong H, Wei L, Hu Y et al (2010). Effect of alendronate on alveolar bone resorption and angiogenesis in rats with experimental periapical lesions. Int Endod J 43: 485491.
Yamada N, Niwa S, Tsujimura T et al (2002). Interleukin-18 and interleukin-12 synergistically inhibit osteoclastic boneresorbing activity. Bone 30: 901-908.

Yamashita J, Koi K, Yang DY et al (2011). Effect of zoledronate on oral wound healing in rats. Clin Cancer Res 17: 1405-1414.

Ziebart T, Pabst A, Klein MO et al (2011). Bisphosphonates: restrictions for vasculogenesis and angiogenesis: inhibition of cell function of endothelial progenitor cells and mature endothelial cells in vitro. Clin Oral Investig 15: 105-111. 